\title{
UJI AKTIVITAS ANTIOKSIDAN EKSTRAK ETANOL BUNGA BROKOLI (Brassica oleracea L. Var Italica) DENGAN METODE DPPH
}

(2,2- difenil-1- pikrihidrazil).

\author{
antioxidant activity Assay of Ethanol Extract Broccoli (Brassica \\ oleracea L. Var Italica) by DPPH Method (2,2 diphenyl-1- \\ picrylhidrazyl)
}

\author{
Rahmawati $^{* 1}$, Sinardi $^{2}$, A.Sry Iryani ${ }^{3}$ \\ 1.2.3Teknik Kimia, Fakultas Teknik, Universitas Fajar
}

Jln. Prof Abdurrahman Basalamah No.101 Makassar, 90231

*Email : Jenk rahma@yahoo.com

\begin{abstract}
ABSTRAK
Brokoli (Brassica oleracea L. Var. Italica) merupakan salah satu tanaman budidaya sayuran yang masuk kedalam familia Brassicecae. Tujuan penelitian ini adalah untuk mengetahui aktivitas antioksidan ekstrak etanol bunga brokoli dengan metode DPPH (2,2- difenil-1- pikrihidrazil). Bunga brokoli diekstraksi secara maserasi menggunakan pelarut etanol, Ekstrak Bunga brokoli dibuat dalam berbagai konsentrasi dan uji aktivitas antioksidan. Dimana nilai $I C_{50}$ ditentukan dengan menghitung analisis regresi terhadap ekstrak etanol bunga brokoli dan vitamin C. Dimana hasil uji fitokimia dari ekstrak etanol bunga brokoli (Brassica oleracea L. Var. Italica) Mengandung senyawa fenol dan flavonoid. Nilai $I C_{50}$ dari ekstrak bunga brokoli (Brassica oleracea L. Var. Italica) sebesar 4998,1 ppm dan IC 50 vitamin C murni 4542,73 ppm memperlihatkan aktivitas antioksidan sangat lemah $\left(I_{50}>200\right.$ ppm).

Kata kunci : Antioksidan, Bunga Brokoli (Brassica oleracea L. var. Italica), metode DPPH
\end{abstract}

\section{ABSTRACT}

Broccoli (Brassica olerace L. var Italica) Is one of the vegetable cultivation plants that enter info familia Brassicecae. The Purpose of this research is to know the antioxidantactivity of broccoli ethanol extract with DPPH method (2,2 diphenyl-1pikrylhidrazyl). Broccoli flowers are extracted by maceration using ethanol solvent, broccoli flower extract is made in various concentration activity test. The $I C_{50}$ value is determined by calculating the regression analysis of the broccoli and vitamin C. The phytochemical extract of broccoli flower extract (Brassica olerace L. var Italica) was $4998.1 \mathrm{ppm}$ and $I C_{50} 4542,73 \mathrm{ppm}$ showed very weak antioxidant activity $\left(I C_{50}>200\right.$ ppm)

Keywords: Antioxidant, Broccoli flower (Brassica Oleracea L. Var italica), DPPH Methode 


\section{PENDAHULUAN}

Antioksidan adalah senyawa yang mampu menghambat laju molekul lain atau menetralisasi radikal bebas. Tubuh kita memerlukan sesuatu antioksidan yang dapat membantu melindungi tubuh dari serangan radikal bebas mengingat begitu banyaknya radikal bebas yang berasal dari luar tubuh yaitu beberapa makanan yang banyak mengandung bahan pengawet, pewarna, asam lemak tidak jenuh , pestisida, polusi, debu dan radiasi ultraviolet [1]

Antioksidan dapat diperoleh dalam bentuk sintetik dan alami. Akan tetapi kekhawatiran terhadap efek samping antioksidan sintetik menjadikan antioksidan alami menjadi aternatif yang terpilih. Antioksidan alami mampu melindungi tubuh terhadap kerusakan oleh spesies oksigen reaktif, mampu menghabat penyakit degenerative serta menghambat peroksidasi lipid pada makanan. Tumbuhan merupakan sumber antioksidan alami dan umumnya merupakan senyawa fenolik yang tersebar pada bagian tumbuhan baik pada kayu, biji, daun, buah, akar, bunga, maupun serbuk sari [2]

Radikal bebas adalah suatu senyawa atau molekul yang mengandung satu atau lebih elektron yang tidak berpasangan pada orbital luarnya. Adanya elektron yang tidak berpasangan menyebabkan senyawa tersebut sangat reaktif mencari pasangan dengan cara menyerang dan mengikat elektron molekul yang berada di sekitarnya seperti lipid, protein maupun DNA [3]. Sayuran jenis Cruciferae (family Brassicaceae) merupakan sumber antioksidanyang berlimpah. Salah satu jenis dari family tersebut adalah tanaman brokoli (Brassica oleracea L. var. Italica). Selain mengkonsumsi suplemen, cara untuk memenuhi kebutuhan antioksidan yaitu dengan mengkonsumsi sayuran. Brokoli merupakan salah satu jenis sayuran yang memiliki kandungankarotenoid, flavonoid, vitamin $A, C, E$, tiamin, riboflavin, betakaroten, lutein dan glutation yang bersifat antioksidan mendapatkan hasil bahwa lutein yang ada pada tanaman brokoli mempunyai antioksidan paling tinggi dibandingkan dengan kubis, kembang kol dan kecambah. Pada penelitian ini dilakukan pengujian antioksidan ekstrak metanol bunga brokoli (Brassica oleracea L. var. Italica). Adanya kandungan zat aktif tersebut maka diperlukan suatu kajian 
mengenai aktivitas antioksidan dengan metode DPPH (2,2 difenil-1-1- pikrihidrazil. [4]

Dalam penelitian ini terdapat beberapa masalah yaitu bagaimana karakterisasi ekstrak bunga Brokoli, berapakah nilai $\mathrm{IC}_{50}$ konsentrasi Ekstrak Bunga Brokoli.

Tujuan dari penelitian ini adalah mengetahui aktivitas antioksidan dari ekstrak etanol Bunga Brokoli (Brassica oleracea L. Var Italica) dengan metode DPPH (2,2- difenil-1- pikrihidrazil).

\section{METODE PENELITIAN}

Metode penelitian terdiri dari bahan dan alat serta prosedur kerja

\section{Bahan}

Bahan yang digunakan dalam penelitian ini yaitu serbuk Bunga Brokoli Aquadest, Etanol 70 \%, Etanol P.a, $\mathrm{FeCl}_{3}$, serbuk Magnesium, $\mathrm{HCl}$ pekat, $\mathrm{DPPH}$

\section{Peralatan}

Alat yang digunakan dalam penelitian ini yaitu Gelas piala, Labu Ukur 50 $\mathrm{ml}$, labu ukur $10 \mathrm{ml}$, Pipet skala 2ml, Micro pipet, kertas saring, Aluminiumfoil, pipet tetes, Tabung reaksi, Toples Kaca, Corong, Spektrovotometer UV-VIS

\section{Prosedur}

Prosedur penelitian terdiri dari persiapan bahan baku, ekstraksi bahan baku, dan analisa produk ekstraksi.

\section{Tahap Persiapan}

Bunga Brokoli dicuci hingga bersih dan dipotong-potong dengan pisau. Dikeringkan dengan cara diangin-anginkan kemudian digiling hingga berbentuk serbuk dan diayak. 


\section{Tahap Pembuatan Ekstrak Etanol Bunga Brokoli}

Serbuk Eceng Gondok ditimbang sebanyak 50 gram kemudian dimasukkan dalam wadah dan diekstraksi secara maserasi $5 \times 24$ jam dengan menggunakan pelarut etanol $70 \%$ sambil sesekali diaduk, kemudian disaring. Ampas hasil ekstraksi kemudian diremaserasi lagi. Filtrate yang diperoleh dikumpulkan dan dipekatkan dengan rotary evaporator sampai diperoleh ekstrak kental.

\section{Uji Pendahuluan Senyawa Fenol dan Flavonoid}

Sejumlah kecil ekstrak kental bunga brokoli dilarutkan dalam $5 \mathrm{ml}$ etanol p.a kemudian ditambahkan pereaksi $\mathrm{FeCl}_{3}$. Sampel positif mengandung senyawa fenol jika terbentuk warna merah, hitam, ungu, biru, dan hijau. (Franswort 1996)

Ekstrak kental bunga brokoli dilarutkan dalam $10 \mathrm{ml}$ etanol p.a, kemudian ditambahkan asam klorida pekat dan serbuk magnesium. Sampel positif mengandung flavonoid jika terbentuk warna merah jingga hingga merah ungu.

\section{Uji Aktivitas Antioksidan}

\section{Pembuatan Larutan DPPH $0.2 \mathrm{mM}$}

DPPH ditimbang sebanyak 3,9433 mg dan dilarutkan detan Etanol p.a hingga $50 \mathrm{ml}$ dalam labu ukur.

\section{Pembuatan Larutan Stok Ekstrak Bunga Brokoli}

Larutan stok 1000 ppm disiapkan dengan cara ditimbang 50 mg ekstrak kental Bunga Brokoli dan dilarutkan dengan Etanol p.a samil dihomogenkan. Volume akhir dicukupkan etanol p.a sampai $50 \mathrm{ml}$ dalam labu ukur.

\section{Pembuatan Larutan stok Vitamin C}

Larutan Stok 1000 ppm disiapkan dengan cara ditimbang 50 mg serbuk vitamin $\mathrm{C}$ dan dilarutkan dengan etanol p.a sambil dihomogenkan, volume akhir dicukupkan etanol sampai $50 \mathrm{ml}$ dalam labu ukur.

4. Pengukuran Aktivitas Antioksidan dengan Metode DPPH

a. Pengukuran serapan larutan Blanko DPPH 
Larutan DPPH $0.2 \mathrm{mM}$ dipipet sebanyak $1 \mathrm{ml}$ dan dicukupkan volumenya sampai $10 \mathrm{ml}$ dengan etanol dalam labu ukur. Larutan ini kemudian dihomogenkan dan dibiarkan selama 30 menit. Selanjutnya serapan diukur dengan spektrofotometri UV-Vis pada panjang gelombang $517 \mathrm{~nm}$. (Molyneux 2004)

b. Pengukuran Aktivitas Pengikat Radikal Bebas DPPH dengan Sampel

Pengujian dilakukan dengan cara memipet masing-masing $800 \mu \mathrm{l}$, $1000 \mu \mathrm{l}, 1200,1400 \mu \mathrm{ldan} 1600 \mu \mathrm{l}$ dari larutan stok sampel bunga brokoli 1000 ppm, campuran ditambah $1 \mathrm{ml}$ DPPH 0,2mM lalu dicukupkan volumenya sampai $10 \mathrm{ml}$ dengan Ethanol p.a sehingga diperoleh larutan dengan konsentrasi 80 ppm, 100 ppm, 120 ppm, 140 ppm dan 160 ppm. Selanjutnya dihomogenkan dandibiarkan selama 30 menit, lalu diukur serapan dengan spektrofotometri UV-Vis pada panjang gelombang $517 \mathrm{~nm}$. Nilai $\mathrm{IC}_{50}$ (50\% Inhibitory Concentration). Konsentrasi sampel dan persen inhibisinya diplot masing-masing pada sumbu $x$ dan y pada persamaan regresi linear. Persamaan tersebut digunakan untuk menentukan nila $\mathrm{IC}_{50}$ dari masing- masin sampel dinyatakan dengan nilai y sebesar 50 dan $\mathrm{x}$ yang akan diperoleh sebagai IC 50 ( Nurjannah dkk, 2011).

c. Pengukuran aktivitas pengikatan Radikal bebas DPPH dengan vitamin C murni

Pengujian dilakukan dengan memipet masing-masing $20 \mu \mathrm{l}, 25 \mu \mathrm{l}$, $30 \mu \mathrm{l}, 35 \mu \mathrm{l}, 40 \mu \mathrm{l}$ dari larutan stok vitamin $\mathrm{C}$ murni 1000 ppm, campuran ditambah $1 \mathrm{ml}$ DPPH 0,2 $\mathrm{mM}$ lalu dicukupkan volumenya sampai $10 \mathrm{ml}$ dengan etanol p.a sehingga diperoleh larutan dengan konsentrasi 2 ppm, 2,5 ppm, 3 ppm, 3,5 ppm, 4 ppm, kemudian dihomogenkan dan dibiarkan selama 30 menit. Selanjutnya serapan diukur dengan spektrofotometri UV-Vis pada panjang gelombang $517 \mathrm{~nm}$. (Molyneux, 2004) 


\section{HASIL DAN PEMBAHASAN}

Penelitian diawali dengan mengekstrak $50 \mathrm{~g}$ simplisia bunga brokoli menggunakan pelarut etanol $70 \%$. Ekstraksi dilakukan selama $5 \times 24$ jam dengan metode maserasi yakni ekstraksi dengan prinsip merendam simplisia dalam cairan penyari pada suhu ruangan sambil sesekali dilakukan pengadukan. Pelarut akan masuk menembus dinding sel kedalam rongga yang mengandung zat aktif, perbedaan konsentrasi pada bagian luar dan dalam sel akan bertukar secara difusi hingga terjadi kesetimbangan.

Tabel 4.1 : Hasil Ekstraksi Bunga Brokoli (Brassica oleacera var. Italica)

\begin{tabular}{|l|l|l|l|l|l|}
\hline Sampel & $\begin{array}{l}\text { Berat } \\
\text { simplisia } \\
(\mathrm{g})\end{array}$ & $\begin{array}{l}\text { Berat } \\
\text { ekstrak } \\
(\mathrm{g})\end{array}$ & $\begin{array}{l}\text { Persentase } \\
\text { rendamen } \\
(\%)\end{array}$ & $\begin{array}{l}\text { Warna } \\
\text { ekstrak }\end{array}$ & $\begin{array}{l}\text { Konsistensi } \\
\text { ekstrak }\end{array}$ \\
\hline $\begin{array}{l}\text { Bunga } \\
\text { Brokoli } \\
\text { (Brassica } \\
\text { oleacera } \\
\text { var. Italica) }\end{array}$ & $50 \mathrm{~g}$ & $3,5397 \mathrm{~g}$ & $7,08 \%$ & $\begin{array}{l}\text { Hijautua } \\
\text { agak } \\
\text { kehitaman }\end{array}$ & $\begin{array}{l}\text { Kental, } \\
\text { setengah } \\
\text { padat }\end{array}$ \\
\hline
\end{tabular}

Persen rendamen yang diperoleh dari ekstraksi menunjukkan kemampuan pelarut dan metode yang digunakan untuk menarik senyawa dalam simplisia. Hasil yang diperoleh adalah ekstrak cair berwarna hijau cerah yang setelah diuapkan pelarutnya menjadi ekstrak kental dengan konsistensi setengah padat berwarna hijau tua kehitaman.

\section{Hasil Uji Fenol}

Pengujian adanya senyawa fenol pada ekstrak etanol bunga brokoli dilakukan dengan cara melarutkan sejumlah sampel dalam $5 \mathrm{ml}$ etanol p.a hingga larut sempurna kemudian menambahkan tetes demi tetes pereaksi $\mathrm{FeCl}_{3}$. Hasil pengujian senyawa fenol disajikan pada Tabel 4.2 . 
Tabel 2. Hasil Pengujian Senyawa Fenol Pada Sampel

\begin{tabular}{|l|l|l|l|}
\hline \multicolumn{1}{|c|}{ Sampel } & \multicolumn{1}{|c|}{ Reaksi } & \multicolumn{1}{|c|}{ Referensi } & \multicolumn{1}{c|}{ Hasil } \\
\hline $\begin{array}{l}\text { Ekstrak Etanol } \\
\text { Bunga Brokoli }\end{array}$ & $+5 \mathrm{ml}$ Etanol p.a & Jingga Kecoklatan & $(+)$ Terjadi \\
& +5 tetes $\mathrm{FeCl}_{3} 1 \%$ & & $\begin{array}{l}\text { perubahan } \\
\text { warna menjadi } \\
\text { Hijau }\end{array}$ \\
& & & \\
\hline
\end{tabular}

Sampel yang larut sempurna dalam $5 \mathrm{ml}$ etanol p.a berwarna jingga kecoklatan, setelah ditambahkan 5 tetes pereaksi $\mathrm{FeCl}_{3}$ terjadi perubahan warna menjadi larutan hijau yang konsisten. Hasil yang diperoleh menunjukkan bahwa sampel positif mengandung senyawa fenolik. (Harborne, 1987)

\section{Hasil Uji Flavonoid}

Hasil uji Flavonoid disajikan dalam Tabel 4.3.

\begin{tabular}{|c|c|c|c|}
\hline Sampel & Reaksi & Referensi & Hasil \\
\hline $\begin{array}{c}\text { Estrak etanol } \\
\text { bunga brokoli }\end{array}$ & $+10 \mathrm{ml}$ etanol p.a & Hijau tua & $\begin{array}{c}(+) \text { Terjadi } \\
\text { perubahan warna } \\
\text { menjadi jingga } \\
\text { kecoklatan }\end{array}$ \\
& $+1 \mathrm{ml} \mathrm{HCl} \mathrm{pekat}$ & & \\
\hline
\end{tabular}

Pengujian kandungan flavonoid dalam ekstrak etanol bunga brokoli dilakukan dengan cara melarutkan sejumlah sampel dalam $10 \mathrm{ml}$ etanol p.a kemudian menambahkan $1 \mathrm{ml} \mathrm{HCl}$ pekat tetes demi tetes dan $50 \mathrm{mg}$ serbuk magnesium sedikit demi sedikit. Sampel yang dilarutkan dengan etanol dan ditambahkan $\mathrm{HCl}$ pekat berwarna hijau tua agak kehitaman, sedangkan setelah ditambahkan serbuk magnesium berangsur - angsur terjadi perubahan warna menjadi jingga kecokelatan. Reaksi antara serbuk magnesium dengan $\mathrm{HCl}$ pekat akan menghasilkan ion magnesium dan hidrogen yang membentuk kompleks 
berwarna merah hingga jingga pada sampel. Hasil yang diperoleh menunjukkan bahwa sampel positif mengandung flavonoid. (Supriyanti 2013).

\section{Hasil Uji Aktivitas Antioksidan Ekstrak Etanol Bunga Brokoli metode DPPH}

Pengujian aktivitas antioksidan dilakukan dengan metode DPPH menggunakan spektrofotometer UV-Vis . Uji aktivitas Ekstrak Bunga Brokoli dilakukan terhadap Radikal bebas DPPH dan Vitamin C sebagai pembanding. Uji aktivitas antioksidan ini dilakukan untuk mengetahui besarnya aktivitas antioksidan masing- masing ekstrak dalam merendam radikal bebas DPPH. Serapan larutan diukur dengan spektrofotometer UV-Vis pada panjang gelombang 400-600 nm.

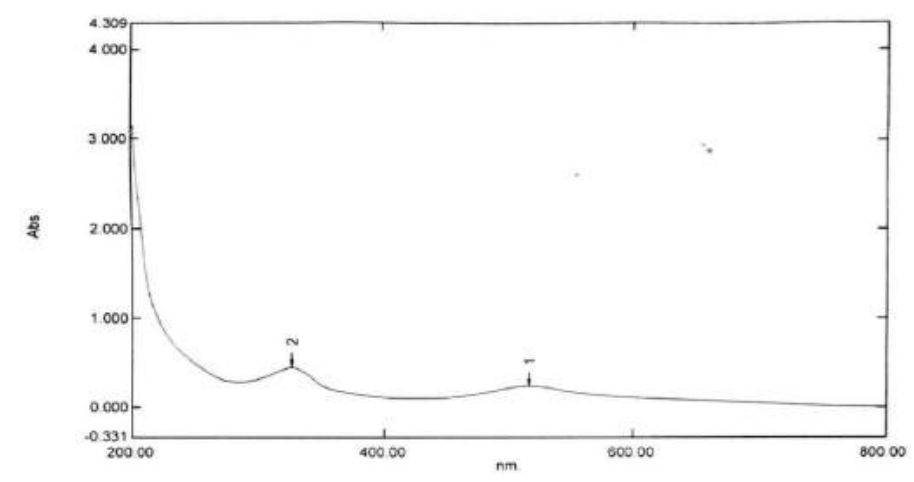

Gambar 4.1 Pengukuran Panjang Gelombang

Absorbansi yang ditujukkan pada panjang gelombang $517 \mathrm{~nm}$ merupakan absorbansi kontrol DPPH, Digunakan Ethanol sebagai blanko. Metode uji aktivitas antioksidan dengan menggunakan DPPH didasarkan pada pengukuran penurunan serapan DPPH pada panjang gelombang maksimum yang sebanding dengan konsentrasi penghambat radikal bebas yang ditambahkan kedalam larutan DPPH. Senyawa DPPH bereaksi dengan senyawa antioksidan melalui pengambilan satu atom hydrogen dari senyawa antioksidan untuk mendapatkan 
pasangan electron, sehingga radikal bebas DPPH akan membentuk senyawa DPPH yang stabill.

Uji aktivitas antioksidan ekstrak bunga brokoli dilakukan dengan menggunakan metode penangkapan radikal bebas DPPH . metode DPPH dipilih karena memerlukan sedikit sampel, sederhana, mudah, cepat dan peka untuk mengevaluasi aktivitas antioksidan dari senyawa bahan alam (Hanani dkk 2005). Pada metode ini DPPH bertindak sebagai model radikal bebas yang akan berikatan dengan senyawa antioksidan (simanjuntak dkk 2004). Uji DPPH ekstrak bunga brokoli bertujuan untuk mengetahui kemampuan aktivitas antioksidan ekstrak kental bunga brokoli. Pengukuran dari hasil uji DPPH menggunakan spektrofotometer dan diperoleh nilai $\mathrm{IC}_{50}$ dapat dilihat pada grafik

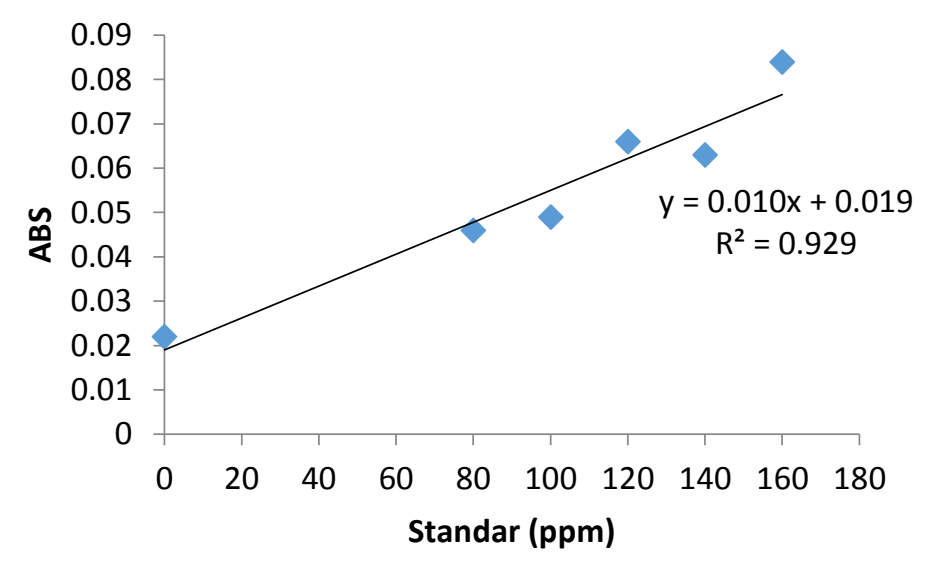

Gambar. 4.2 Grafik Analisis Ekstrak Bunga Brokoli

Mekanisme penangkapan radikal DPPH oleh senyawa antioksidan adalah melalui donasi atom hydrogen dimana terjadi rentang waktu masa inkubasi sampel yang bercampur dengan reagen DPPH selama 30 menit sehingga menyebabkan perubahan warna DPPH dari ungu menjadi kuning (Hanani dkk 2005). Perubahan warna tersebut disebabkan karena berkurangnya ikatan rangkap terkonjugasi pada DPPH karena adanya penangkapan satu elektron oleh senyawa antioksidan yang menyebabkan tidak adanya kesempatan elektron tersebut untuk beresonansi 
dimana perubahan ini dapat diukur dan spektrofotometer ekstrak Etanol Bunga Brokoli yang memiliki aktivitas antioksidan. Proses reaksi antara senyawa antioksidan dengan radikal DPPH terjadi melalui mekanisme donasi atom hydrogen (Purwangsih 2012)

Berdasarkan hasil penelitian terlihat bahwa dari persamaan regresi dari ekstrak etanol bunga brokoli yaitu $Y=0.010 x+0.019$ dan $x=4998,1 \mu \mathrm{g} / \mathrm{ml}$. nilai $\mathrm{IC}_{50}$ diperoleh dari persamaan regresi linier yaitu nilai $\mathrm{x}$ tersebut. Hasil dari perhitungan nilai y sebesar 50 akan memberikan nilai $x$.

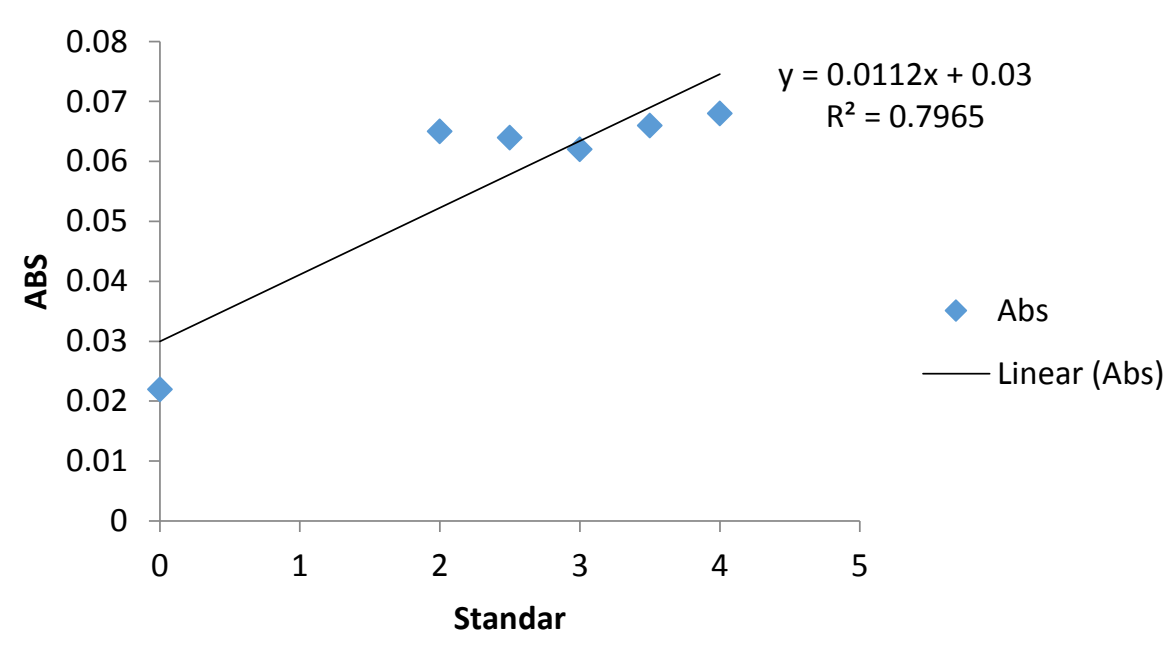

Gambar 4.3 Grafik Analisis Nilai Asam Askorbat

Selanjutnya data hasil pengukuran Asam Askorbat pada kontrol positif diperoleh persamaan nilai regresi $y=0.011 x+0.03$ dan $x=4542,73 \mu \mathrm{g} / \mathrm{ml}$. Nilai $\mathrm{IC}_{50}$ diperoleh sangat lemah. Dalam pembuatan kurva standar ini menggunakan 5 
larutan standar yang telah diketahui konsentrasi nilai $\mathrm{R}$ merupakan bilangan yang menunjukkan tingkat keakuratan dan ketelitian dari larutan standar yang kita buat. Apabila nilai $\mathrm{R}$ mendekati 1 maka kurva standar tersebut semakin bagus. $\mathrm{R}$ memiliki nilai maksimum 1 tidak pernah lebih dari 1. Menurut Molyneaux (2004) menjelaskan bahwa klasifikasi antioksidan dibagi menjadi 5 yaitu, kuat $<50$ ppm (sangat kuat), 50-100 ppm (kuat), 100-150 ppm (sedang), 150-200 ppm (lemah) dan >200 ppm adalah sangat lemah. Karena dipengaruhi oleh larutan DPPH tersebut dimana DPPH memiliki sifat hidrofobik, yaitu tidak larut dalam air dan dan hanya bisa larut dalam pelarut organik. Oleh karena itu, metode DPPH terbatas hanya pada antioksidan. Larutan stok DPPH mudah bereaksi dengan cahaya dan oksigen, sehingga dapat mengalami degradasi. Untuk menghindari atau mmeminimalisir hal tersebut, maka larutan stok harus ditutup dengan aluminium foil dan disimpan ditempat yang gelap. Dengan begitu, larutan stok DPPH dapat bertahan hingga 1 minggu.

\section{KESIMPULAN}

Berdasarkan hasil penelitian yang telah dilakukan, maka dapat disimpulkan bahwa

1. Senyawa yang terkandung dalam ekstrak etanol berupa fenol, dan flavonoid.

2. Ekstrak Bunga Brokoli memiliki nilai aktivitas antioksidan dengan nilai $I C_{50} 4.998,1$ ppm sedangkan dengan sebagai kontrol positif nilai I $\mathrm{C}_{50}$ vitamin $\mathrm{C} 4542,73$ ppm $\left(\mathrm{IC}_{50}>200\right.$ ppm) tergolong sangat lemah.

\section{DAFTAR PUSTAKA}

Anastasia kazia Friany Lisi, Max R. J.Runtuwenw, Defny s. wewengkang (2017) uji Fitokimia dan Aktivitas Antioksidan dari Ekstrak methanol Bunga Soyogik (saurania bracteosa DC). Jurnal ilmiah farmasi ISSN 2302-2493

Farnsworth, N/ R. (1996). Biological and Phytochemical screening of plants. Journal of Pharmaceutical Sciences. Hal 225-276 
Hanani , E. Mun'im, A \& Sekarini ,R (2005). Identifikasi senyawa antioksidan dalam spons Callyspongia sp. Dari kepulauan seribu. Majalah ilmu kefarmasian. ISSN : 1693-9883. Vol. II. No.3 : 127

Harbone, J.B (1996). Metode Fitokimia, terjemahan K. Padmawinata, i. Soediro, Terbitan Kedua, Institut Teknologi Bandung Press, Bandung.

Molyneux, p. (2004), The use of the stable freee radical diphenylpicryl hidrazyl (DPPH) foe estimating antioxidant activity. Songklanakarin J. Sci. Technol.hal 211-219

Nurjannah, Abdullah, A, Izzati (2011). Aktivitas Antioksidan dan komponen Bioaktif kerang pisau (solen spp. Jurnal ilmu kelautan 16

Jusuf, Nelva Karnila (2012) Pengaruh Ekstrak Bunga Brokoli (Brassica Oleracea L. Var Italica Plenk ) Terhadap penghambatan penuaan kulit dini (Photoaging). Kajian pada Ekspresi Matriks Metalloproteiinase-1 dan Prokolagen Tipe 1 secara in vitro pada Fibroblas manusia. Medan. Fakultas Kedokteran Sumatra Utara

Purwangsih, S 2012. Aktivitas Antioksidan dan Komposisi kimia keong Matah Merah(cerithidea obtusa. Ilmu kelautan. ISSN 0853-7921. Vol.17 (1) 39-48.

Winarsih,H. 2007. Antioksidan Alami dan Radikal Bebas. Yogyakarta: Kanisius

Simanjuntak. P , Parwati, T. Lenni LE, tamat, R. Murwani, R (2004) Isolasi \& identifikasi antioksidan dan ekstrak Benalu Teh isolasi ortiana (korth denses). Jurnal ilmu kefarmasian Indonesia ISSN: 1693-1851:5(1): 19-24,

Sunarni, T., pramono S. Asmah R.(2007). Flavonoid Antioksidan penangkapan radikal dari daun kepel (Stelechocarpus burahol (BI) Hook $f$ \& Th). Majalah farmasi Indonesia. Hal 111-116 